\title{
The dynamics of primary growth in woody species from rain and transitional forests of Argentinean north Patagonia
}

\author{
Dinámica del crecimiento primario de especies leñosas en bosques lluviosos \\ y de transición de la Patagonia Norte, Argentina
}

\author{
Mariana Salgado ${ }^{\text {a*}}$, Cristian Daniel Torres ${ }^{\text {b }}$, Amaru Magnin ${ }^{\text {b,c }}$, Marina Gerea ${ }^{\text {b }}$, \\ Javier Edgardo Grosfeld ${ }^{\text {d,e }}$, Javier Guido Puntieri a , Marina Stecconi ${ }^{\text {b }}$ \\ *Corresponding author: ${ }^{a}$ Universidad Nacional de Río Negro-CONICET, \\ Instituto de Investigaciones en Recursos Naturales, Agroecología y Desarrollo Rural, \\ 8400 John O’Connor 181, Bariloche, Argentina, tel.: 549 2944437496, msalgado@unrn.edu.ar \\ ${ }^{\mathrm{b}}$ Universidad Nacional del Comahue-CONICET, Instituto de Investigaciones en Biodiversidad y Medio Ambiente, \\ 8400 Bariloche, Argentina. \\ ${ }^{\mathrm{c}}$ Alfred-Wegener-Institut, Helmholtz-Zentrum für Polar und Meeresforschung, \\ Biologische Anstalt Helgoland, 27498 Helgoland, Germany. \\ ${ }^{\mathrm{d}}$ Centro Científico Tecnológico Patagonia Norte, CONICET, 8400 Bariloche, Argentina. \\ eAdministración de Parques Nacionales, Dirección Regional Patagonia Norte, 8400 Bariloche, Argentina.
}

SUMMARY

Rainforests (RF) and transitional forests (TF) of Argentinean north Patagonia develop under such different climatic conditions that key aspects of seasonal growth may be assumed to differ among the woody plants that characterize these forests. This study was aimed at evaluating primary growth dynamics in tree species typical of RF and TF. Two common-garden essays were performed in Bariloche, Argentina, one with RF species and the other with TF species. The times of extension initiation and end, the duration of the extension period and the relative and absolute extension rates (RER and AER, respectively) were registered for each species. The relation between AER and air temperature was compared between species. In general, RF species had less variable times of extension initiation, extension end and time of maximum RER, and longer-lasting extension than TF species. Among RF species, extension duration was the longest for Caldcluvia paniculata (26.9 weeks, on average) and the shortest for Luma apiculata (18.9 weeks). Among TF species, the longest and shortest extension durations corresponded, respectively, to Diostea juncea (18.2 weeks) and Maytenus boaria (13.0 weeks). The extension rates of RF species tended to be more related to temperature than those of TF species. This study provides some evidence that endogenous control of growth dynamics would be tighter in TF than in RF species; the former would be better adapted to more severe climatic conditions during the primary-growth period.

Key words: Patagonian forest, plant architecture, primary growth, annual shoots, seasonal growth.

\section{RESUMEN}

Los bosques lluviosos (RF) y los bosques de transición (TF) de Patagonia Norte argentina se desarrollan bajo condiciones climáticas contrastantes, por lo que puede esperarse que las especies leñosas que caracterizan estos dos tipos de bosque difieran en aspectos clave del crecimiento estacional. Este estudio tuvo como objetivo evaluar la dinámica de crecimiento primario de especies arbóreas típicas de RF y de TF, mediante dos ensayos en jardín común en Bariloche, Argentina. Para cada especie se registraron las fechas del inicio y fin, y duración del alargamiento. Se calcularon las tasas de alargamiento relativas (RER) y absolutas (AER), relacionando las últimas con la temperatura. En general, las especies de RF tuvieron momentos de inicio del alargamiento, fin de alargamiento y RER menos variables y períodos de alargamiento más largos que las de TF. Entre las especies de RF, Caldcluvia paniculata tuvo el período de alargamiento más largo y Luma apiculata el más corto (26,9 y 18,9 semanas, respectivamente). Entre las especies de TF, Diostea juncea tuvo el período de alargamiento más largo y Maytenus boaria el más corto (18,2 y 13,0 semanas, respectivamente). Las AER de las especies de RF estuvieron más relacionadas con la temperatura que las de TF. Este estudio aporta evidencia que sugiere que la dinámica de crecimiento en especies del TF está sujeta a mayor control endógeno que en especies de RF; las especies del TF estarían mejor adaptadas a condiciones climáticas más estrictas durante el período de crecimiento primario.

Palabras clave: bosques patagónicos, arquitectura vegetal, crecimiento primario, brotes anuales, crecimiento estacional. 


\section{INTRODUCTION}

Axis length growth in woody plants, also known as primary growth (organogenesis followed by extension), is controlled by the interaction of endogenous and environmental forces, and has a key influence on the ability of a species to adapt to external conditions (Barthélémy and Caraglio 2007). Primary-growth patterns of woody plants have been extensively studied for many purposes, e.g. to understand the way plant architecture takes form, and to unravel the adaptive physiological mechanisms underlying plant architecture (Isik et al. 2002). The interaction between endogenous and environmental effects on extension and architecture has been investigated using different scientific approaches (Gordon et al. 2006). A species basic extension pattern may be analyzed through field studies that include populations at dissimilar areas within the species range, although severe restrictions derive from multiple variability sources. For instance, the primary growth of annual shoots is highly variable within and between species as a result of both the expression of ontogenetic gradients, and the influence of environmental factors (Barthélémy and Caraglio 2007, Magnin et al. 2016). Common-garden experiments are useful in this regard, as ontogenetic, environmental and size-related variability sources would be better controlled (Premoli et al. 2007). Since common-garden experiments allow all plants to be subject to even conditions, growth attributes driven mainly by endogenous or genetic factors would be evidenced.

Two basic patterns of primary growth dynamics have been described: continuous and rhythmic. Continuous growth is defined by the lack of a clearly identifiable growth period due to the absence of endogenous limitations, so that plants grow whenever external conditions are favorable (Barthélémy and Caraglio 2007). Rhythmic growth is characterized by an endogenous determination of a period of shoot growth followed by a resting period, which occurs even when external conditions are favorable for vegetative growth. In general terms, the primary growth of trees from temperate and cold regions takes place in the period of the year when climatic conditions are most favorable to the species concerned (Stecconi et al. 2000). In some temperate regions, the limits of that period may not be easy to establish as climatic conditions exhibit relatively smooth seasonal variations. It may be hypothesized that primary-growth patterns could change, in evolutionary time, from continuous to rhythmic or vice-versa. This hypothesis may be tested by means of the evaluation of endogenous and environmental influences on the primary growth of woody plants (Buissart et al. 2018). Such information is highly interesting, considering that current global tendencies point to increments in climatic variability for temperate regions (Matthews et al. 2016), which would impact on plant fitness in future scenarios.

In Argentinean northern Patagonia, a sharp decrease in precipitations from west to east, ranging from 3500 to 600 $\mathrm{mm} / \mathrm{year}$, is evident within $50 \mathrm{~km}$ east of the Andes Mountains due to a rainshadow effect (Conti 1998). Plant communities vary, respectively, from temperate rainforests to steppe. Forests at the western end of this gradient are included in the so-called "Valdivian rainforest", and are considered a hotspot of biodiversity (Myers et al. 2000), with diverse evergreen tree species, some of which belong to Neotropical lineages and others to Gondwanan lineages (Aizen and Ezcurra 1998). Two of the main climatic factors that condition primary-growth dynamics, rainfall and temperature, have increased their ranges of within-year variation from these rainforests eastwards (Donoso 2013, Stecconi et al. 2017), due to the buffering effects of the humid winds from the Pacific Ocean since the elevation of the Andes, about 25 m.y. ago (CONAMA 2008). Towards the dry end of this precipitation gradient, those forests that are transitional between the rainforests and the steppe (hereafter transitional forests) are often subject to below-zero temperatures in spring and summer, and to long summer periods of water deficit (Kitzberger 2012). These factors would have a major influence on the lower richness of woody species of transitional forests compared to that in the nearby rainforests.

Climate models for Patagonia predict a trend towards decreasing water inputs (Bates et al. 2008), with more frequent and/or intense drought periods. It has been shown for several tree species that fitting primary growth to the time window with suitable conditions has key importance in the likelihood of inhabiting a particular region (Sow et al. 2018). A better understanding of which factors are more involved in the regulation of tree growth may contribute in the prediction of species responses to eventual climatic changes in this or other regions, and would mean a step forward in explaining evolutionary variations in the extension patterns of plants. In the present study, we evaluated the extension dynamic of annual shoots (times of extension start and end, rates and duration) and the relationships between extension rate and mean temperature fluctuations for woody species typical of transitional forests (four species) and rainforests (four species) of Argentinean North Patagonia. We hypothesized that intra-annual variations in precipitations and temperatures are strong selective forces that contribute to modifying endogenous patterns in the primary growth dynamics of tree species. Since rainforests in Argentinean Patagonia are subject to less sharp seasonal changes in temperature and humidity than transitional forests, we expect that primary-growth patterns of rainforests species would express tighter responses to environmental conditions during the growth season than those of transitional forest species; the latter would exhibit stronger endogenous controls of shoot extension.

\section{METHODS}

Study species. The study included individuals from eight native woody species, which were assigned to one of two 
groups in accordance to their natural habitat. All of them were produced from seeds in greenhouse and maintained in nursery with periodic watering up to the beginning of this study:

- Transitional forest species: comprised five-yearold individuals of the following species: Aristotelia chilensis (Molina) Stuntz (Elaeocarpaceae; $\mathrm{n}=25$ ), Maytenus boaria Molina (Celastraceae; $\mathrm{n}=25$ ), Schinus patagonicus (Phil.) I.M. Johnst. (Anacardiaceae; $\mathrm{n}=25$ ) and Diostea juncea (Gill. et Hook.) Miers (Verbenaceae; $\mathrm{n}=25$ ), and

- Rainforest species: comprised three- to five-yearold individuals in all cases of: Luma apiculata (DC.) Burret (Myrtaceae; $\mathrm{n}=20$ ), Gevuina avellana Molina (Proteaceae; $\mathrm{n}=22$ ), Caldcluvia paniculata (Cav.) D. Don. (Cunoniaceae; $\mathrm{n}=15$ ) and Weinmannia trichosperma Cav. (Cunoniaceae; $\mathrm{n}=20$ ). The minimum number of individuals per species was 15 , taking into account the number of plants commonly used in primary growth dynamics research (e.g. Poorter et al. 2006; Stecconi et al. 2017; Buissart et al. 2018).

Transitional forest species are native to transitional communities between the steppe-forest ecotone and the rainforests. Aristotelia chilensis is wintergreen, M. boaria and S. patagonicus are evergreen, and D. juncea is deciduous (though it has green stems). All four selected rainforest species are evergreen trees typical of the temperate rainforests of Chile and Argentina. Every specimen derived from seeds obtained from Argentinean natural populations. We assumed that all plants were at the same architectural stage based on architectural characteristics, the absence of flowers and the clearly defined vertical trunk (Gerea 2008; Salgado 2018). These two species groups were established in different nurseries in San Carlos de Bariloche (transitional forests: $41^{\circ} 08^{\prime} \mathrm{S} 71^{\circ} 18^{\prime} \mathrm{W}, 880 \mathrm{~m}$ a.s.l.; rainforests: $41^{\circ} 11^{\prime} \mathrm{S} 71^{\circ} 44^{\prime} \mathrm{W}, 818 \mathrm{~m}$ a.s.l.). The reason for growing transitional forest and rainforest species in two different nurseries was based on the fact that these two species groups differ in their optimal levels of water and light.

Measurements. Data regarding each group was collected independently, in different growth seasons: 2006-2007 for rainforests and 2016-2017 for transitional forests. At the beginning of the respective growth season (August), the base of the apical bud of each plant main axis (the most vigorous and vertical) was marked with a paint pen. During the growth season, the length of the shoot developed from each marked bud, from the basal mark to the distal end of the apical bud, was measured weekly with a measuring tape (to the nearest $\mathrm{mm}$; figure 1).

Data analyses. The dates of extension initiation and cessation were registered for each shoot. Weekly absolute ex-

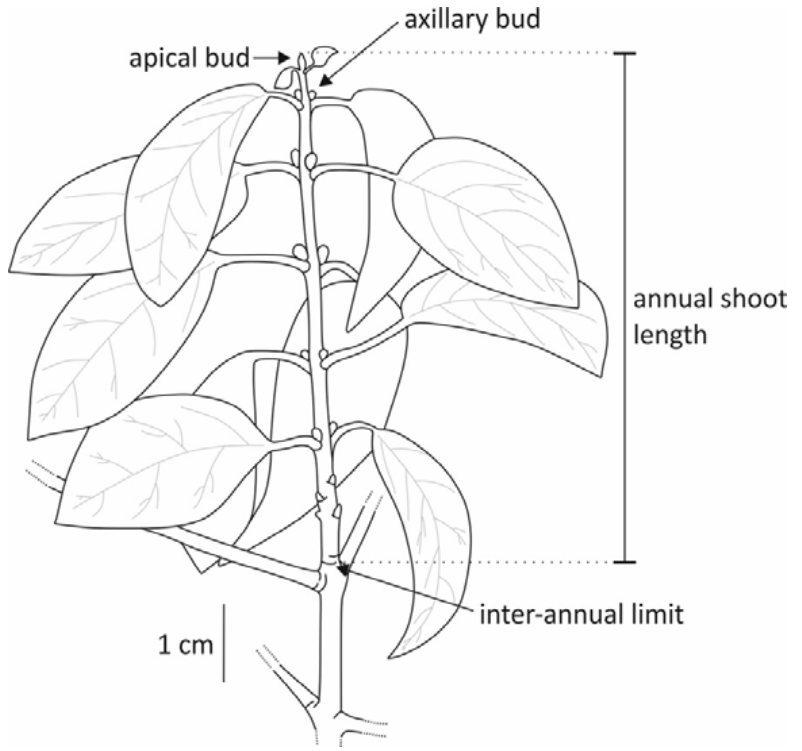

Figure 1. Diagrammatic representation of an annual shoot of Aristotelia chilensis. The apical bud, an axillary bud and the inter-annual limit between two successive shoots are indicated.

Diagrama de un brote anual de Aristotelia chilensis. Se indican la yema apical (apical bud), una yema axilar (axillary bud) y el límite interanual entre dos brotes sucesivos (inter-annual limit).

tension rate (AER) and relative extension rate (RER) were calculated for each plant according to equations [1] and [2]:

$$
\begin{gathered}
\mathrm{AER}=\frac{L 2-L 1}{t 2-t 1} \times 7 \\
\mathrm{RER}=\frac{\ln (L 2)-\ln (L 1)}{t 2-t 1} \times 7
\end{gathered}
$$

where $\mathrm{L} 1$ and $\mathrm{L} 2$ are shoot lengths at dates $\mathrm{t} 1$ and $\mathrm{t} 2$, respectively. So that $\mathrm{t} 2-\mathrm{t} 1$ is the number of days between these dates.

Extension duration was calculated as the number of weeks from extension initiation to extension end. The intra-specific standard errors (SE) of the moments of extension initiation, maximum RER ( RER $_{\text {max }}$ ) and extension end were calculated for each species. Within each species group, inter-specific variations in RER and extension duration were analyzed by means of one-way ANOVA. Spearman correlations between centered and standardized data of average weekly AER and temperature were computed for each species (mean temperatures obtained from Dirección de Aguas Rionegrinas). To qualitatively evaluate the relationship between AER and temperature variations, an analysis of the proportion of coincidences of weekly increases or decreases of both variables during the extension period of each plant was performed. These data were com- 
pared between species (main factor) by means of Generalized Linear Models, assuming a binomial error distribution and a log-link function. This model was contrasted against the null model by means of a chi-square test of sequential deviance followed by Tukey's pairwise comparisons on the multcomp package. All statistical analyses were performed with R software (R Development Core Team 2014), assuming a $5 \%$ significance level in all comparisons.

\section{RESULTS}

For most species, shoot extension started by early September, except for $W$. trichosperma, which had a slightly later budbreak (figure 2). Gevuina avellana, M. boaria and $S$. patagonicus showed the highest standard errors for the date of extension initiation, whereas lower variations were observed for the other species. Some individuals
Rainforest

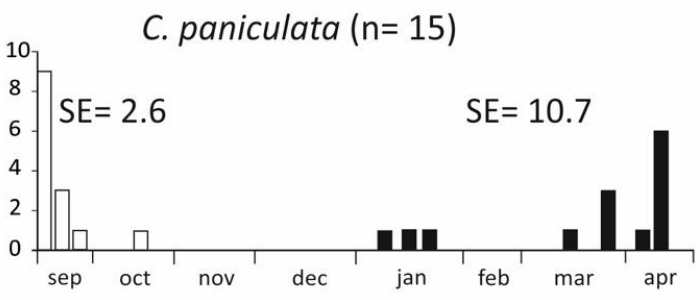

W. trichosperma $(n=20)$
Transitional Forest

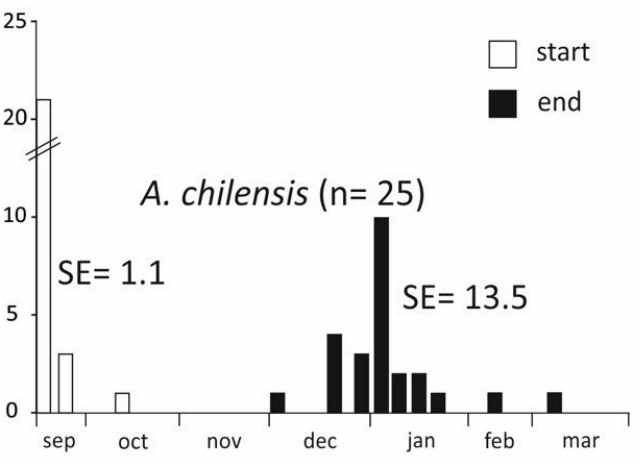

M. boaria $(n=25)$
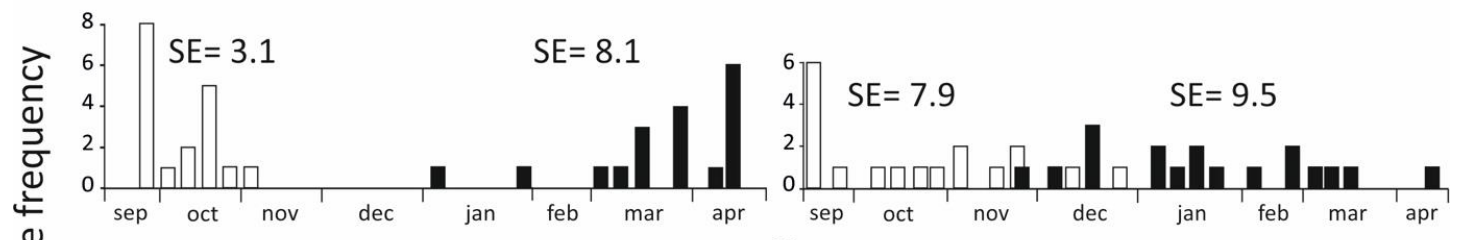

G. avellana $(n=22)$
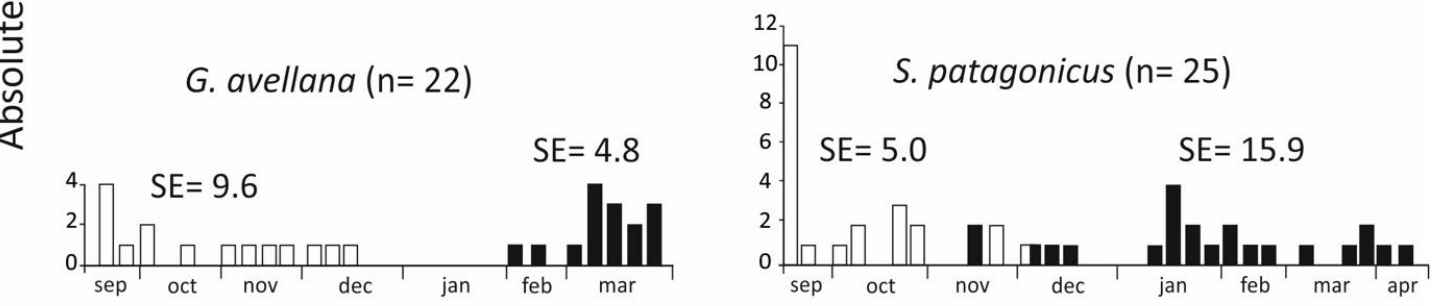

L. apiculata $(n=20)$
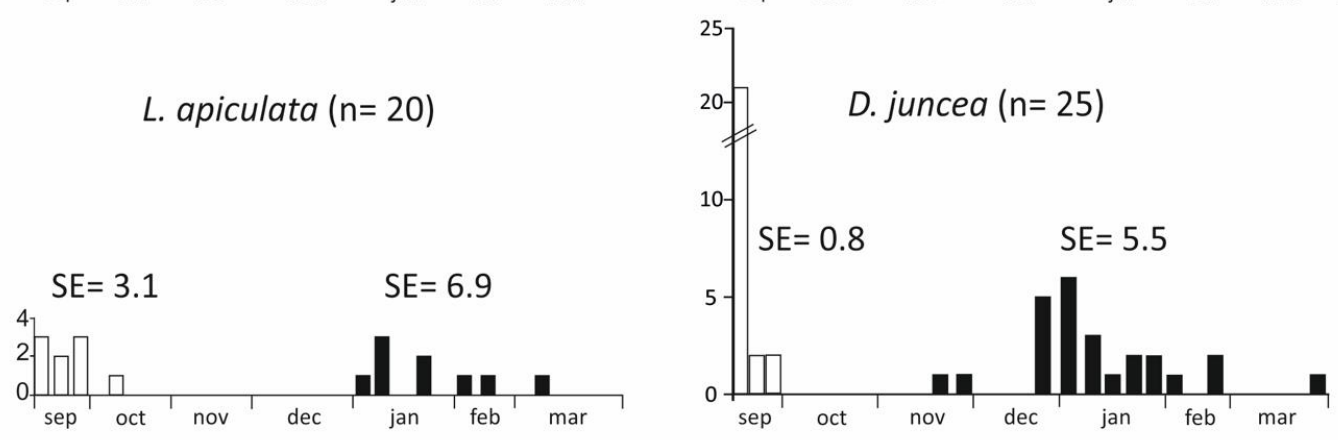

Time (month)

Figure 2. Frequency distributions of the times of shoot extension initiation (white bars) and end (black bars) for each of the eight species under survey. Above the white and black bars are the standard errors (SE) of extension initiation and end, respectively. Next to each species name are the number of individuals (n) studied. Left graphs: rainforest species, right graphs: transitional forest species.

Distribuciones de frecuencias de los momentos de inicio (barras blancas) y fin (barras negras) del crecimiento del brote para cada especie estudiada. Sobre las barras blancas y negras se encuentran los errores estándar (SE) del inicio y del fin del crecimiento, respectivamente. Al lado del nombre cada especie está el número de individuos (n) estudiados. Izquierda: especies de bosque lluvioso; derecha: especies de bosque de transición. 
of M. boaria and S. patagonicus initiated their extension at a time when other co-specific individuals had already ended their extension periods. For the remaining species, extension initiation and end were several weeks apart. The time of $\mathrm{RER}_{\max }$ was little variable in most rainforest species (considering the $\mathrm{SE}$ of this variable) and increased in this order: D. juncea $(\mathrm{SE}=2.0)$, A. chilensis $(\mathrm{SE}=2.9)$, W. trichosperma $(\mathrm{SE}=3.0)$, C. paniculata $(\mathrm{SE}=3.3)$, L. apiculata $(\mathrm{SE}=3.6)$, S. patagonicus $(\mathrm{SE}=6.0)$, M. boaria $(\mathrm{SE}=6.2)$, G. avellana $(\mathrm{SE}=6.7)$. Among rainforest species, C. paniculata and $W$. trichosperma presented the latest extension ends (up to April). Most L. apiculata shoots ended growing between January and February, whereas in the case of G. avellana, extension end was mostly concentrated in March. The highest variations in extension end were observed for two transitional forest species (A. chilensis and S. patagonicus) and the lowest one, for a rainforest species (G. avellana).

Among rainforest species (figure 3A) extension duration was longer for $C$. paniculata and $W$. trichosperma (26.9 and 24.3 weeks on average, respectively) than for L. apiculata and G. avellana (18.9 and 20.7 weeks). Signi- ficant variations between these species were confirmed by statistical analyses $(\mathrm{F}=8.38 ; P<0.001)$. For transitional forest species, extension duration tended to be shorter than 20 weeks; Maytenus boaria and S. patagonicus presented, on average, shorter extension durations (13.0 and 15.7 weeks, respectively) than those presented by $A$. chilensis and $D$. juncea (18.0 and 18.2 weeks; $\mathrm{F}=5.82 ; P<0.001$; figure 3C). The lowest $\mathrm{RER}_{\max }$ among RF species was that for $W$. trichosperma; all other rainforest species did not differ in this variable (figure 3B; $\mathrm{F}=8.94 ; P<0.001$ ). Regarding transitional forest species, $\mathrm{RER}_{\text {max }}$ was the lowest for A. chilensis and the highest for S. patagonicus (figure 3D; $\mathrm{F}=17.28 ; P<0.001)$.

Weekly variations in absolute extension rate (AER) were associated with mean temperature variations during a limited period for most species (figure 4). AER was significantly correlated with weekly temperature only for W. trichosperma and G. avellana (Spearman's coefficient $=0.45$ and 0.54 , respectively). Gevuina avellana had only one peak in AER, which occurred during the period of highest temperatures. Caldcluvia paniculata, A. chilensis, L. apiculata and D. juncea had their highest AER during
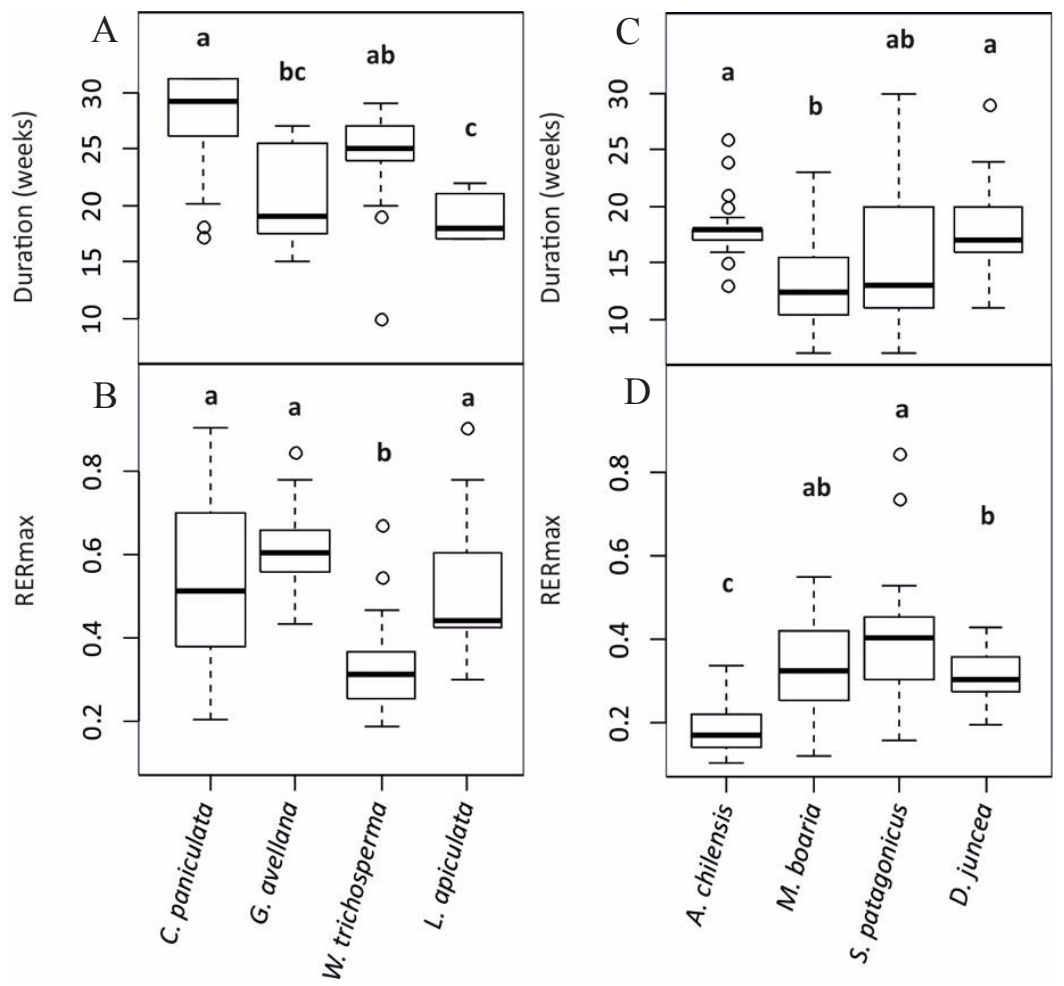

Figure 3. Extension duration and maximum relative extension rate for rainforest (A and $B$ ) and transitional forest (C and D) species. Boxes represent the range between $25 \%$ and $75 \%$ percentiles. Circles represent outlying data. The line in the box represents the median and whiskers mark the $5 \%$ and $95 \%$ percentiles. Different letters indicate significant differences obtained by statistical analyses.

Duración del alargamiento y tasa de alargamiento relativo máxima (RERmax) para las especies del bosque lluvioso (A y B) y para las de bosque de transición (C y D). Las cajas representan el rango entre los percentiles de $25 \%$ y 75 \%. Los círculos representan datos atípicos. La línea horizontal dentro de la caja representa la mediana y los bigotes marcan los percentiles del $5 \%$ y $95 \%$. Las especies con letras iguales encima de sus cajas no difieren estadísticamente. 
the first half of their respective extension periods, coinciding with increments in mean temperature. Increases in AER during the second half of the extension periods of these species did not go along with increases in temperature. It is worth noticing the increment in AER registered for C. paniculata close to the end of its extension period, which corresponded to a second growth flush in most individuals (figure 4). A second peak in the AER of $W$. trichosperma paralleled a December-January temperature increment. Maytenus boaria and S. patagonicus had several peaks in AER during the growth season. The degree of coincidence of weekly increases and decreases in tempe- rature and AER, as evaluated through a binomial model, was variable among species (residual deviance null model $=186.36$, residual deviance model with species $=145.9$; $P<0.001)$. Overall, higher coincidences were observed for rainforest species than for transitional forest species, although the most contrasting results were those observed for $W$. trichosperma and $D$. juncea, for which the highest and the lowest levels of coincidence, respectively, were observed (table 1). Statistical differences were confirmed between $D$. juncea and all rainforest species, between $D$. juncea and A. chilensis, and between A. chilensis and $W$. trichosperma.

\section{Rainforest}
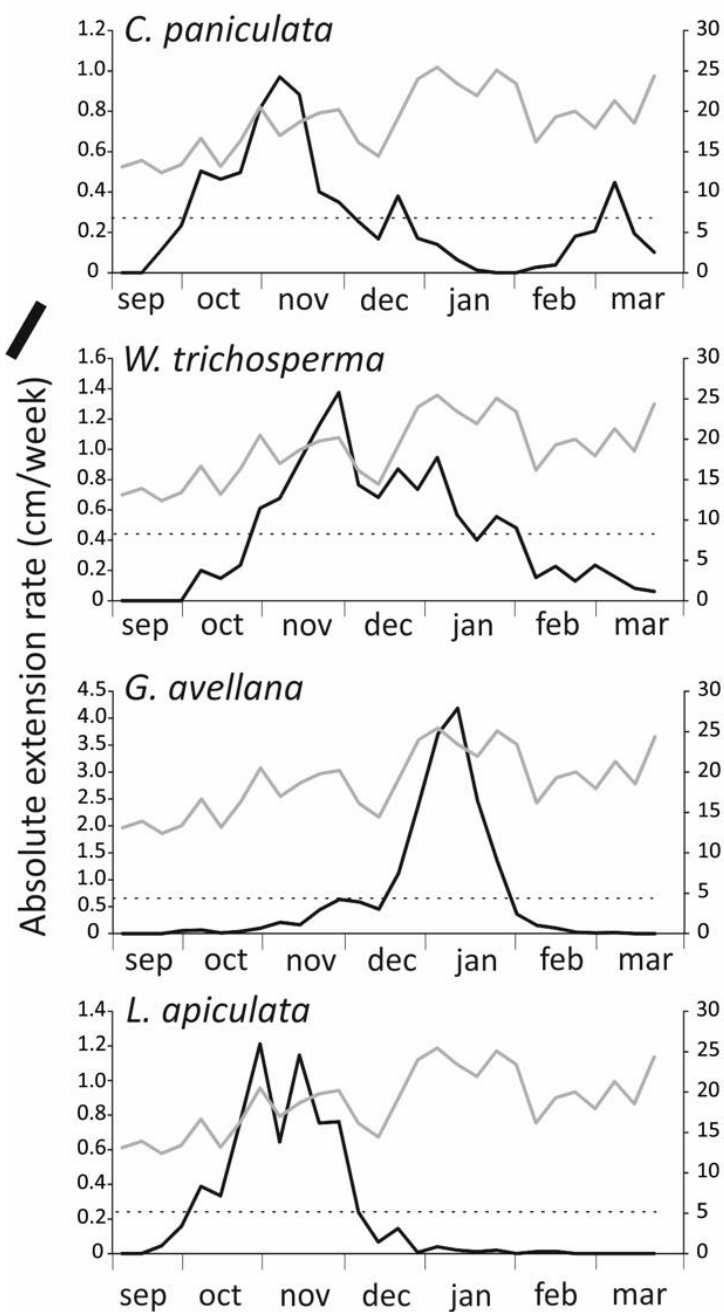

\section{Transitional Forest}
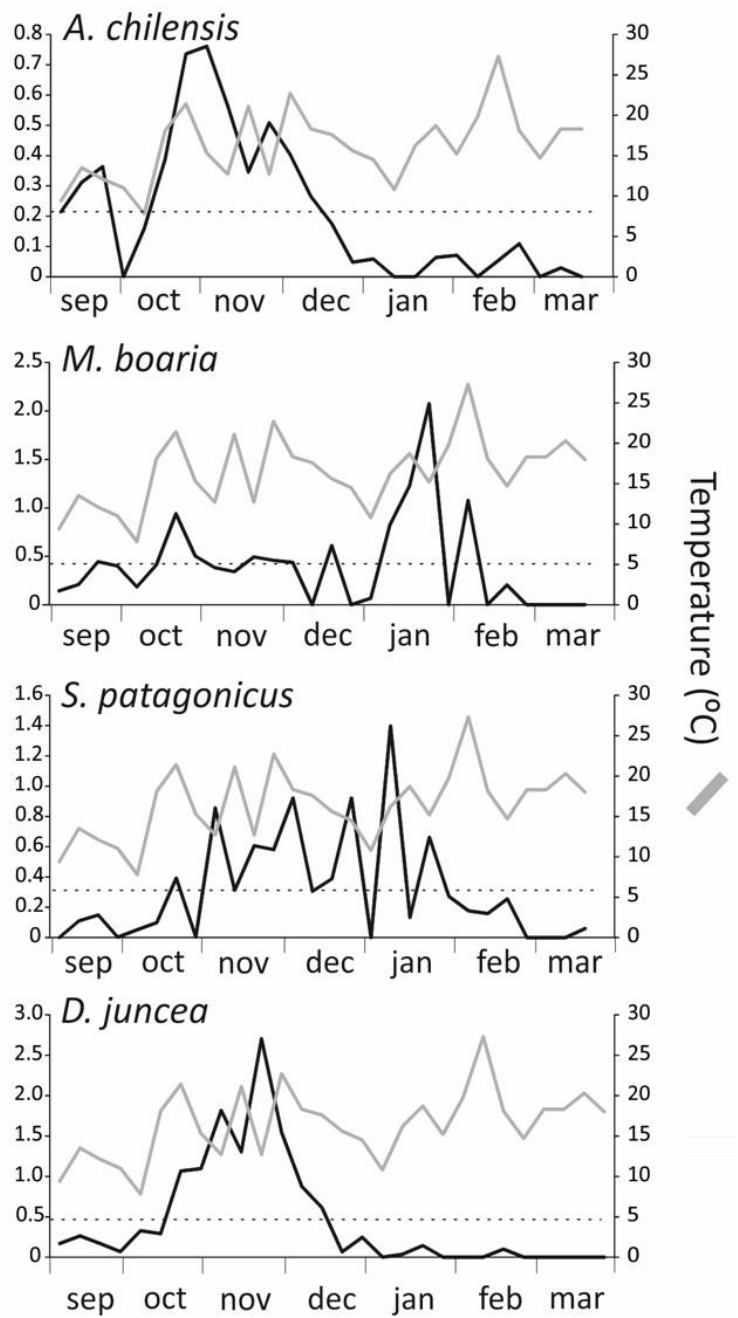

Time (month)

Figure 4. Mean absolute extension rate (AER) for each species (in black) and mean weekly temperature (in gray) for the observation periods. In each graph the average AER of each species is shown with a straight dashed line. Left graphs: rainforest species; right graphs: transitional forest species.

Tasa de alargamiento absoluto (AER) media de cada especie (en negro) y la temperatura semanal media (en gris) para los períodos de observación. En cada gráfico se muestra la AER promedio de cada especie como línea recta punteada. Gráficos a la izquierda: especies del bosque lluvioso; y gráficos de la derecha: especies del bosque de transición. 
Table 1. Mean proportion of coincidence between weekly variations in absolute extension rate (AER) and temperature for the studied species (RF: rainforest species; TF: transitional forest species). Results of pairwise Tukey's comparisons are provided.

Proporción media de coincidencia entre variaciones semanales en la tasa de alargamiento absoluta (AER) y temperatura para cada especie estudiada (RF: especies de bosque lluvioso; TF especies de bosque de transición). Se proveen los resultados de comparaciones de a pares de Tukey.

\begin{tabular}{lccc}
\hline Species & Group & Proportion of coincidence & Tukey's groups \\
\hline Gevuina avellana & $\mathrm{RF}$ & 0.60 & $\mathrm{AB}$ \\
Caldcluvia paniculata & $\mathrm{RF}$ & 0.56 & $\mathrm{AB}$ \\
Weinmannia trichosperma & $\mathrm{RF}$ & 0.65 & $\mathrm{~A}$ \\
Luma apiculata & $\mathrm{RF}$ & 0.65 & $\mathrm{AB}$ \\
Aristotelia chilensis & $\mathrm{TF}$ & 0.54 & $\mathrm{~B}$ \\
Schinus patagonicus & $\mathrm{TF}$ & 0.54 & $\mathrm{ABC}$ \\
Maytenus boaria & $\mathrm{TF}$ & 0.53 & $\mathrm{ABC}$ \\
Diostea juncea & $\mathrm{TF}$ & 0.42 & $\mathrm{C}$ \\
\hline
\end{tabular}

\section{DISCUSSION}

Growth dynamics parameters. This study was aimed at evaluating extension patterns of groups of woody species typical of rainforests and transitional forests in North Patagonia; these two forest types are subject to contrasting climatic conditions, nonetheless are geographically close to one another (less than $50 \mathrm{~km}$ apart). Our study includes the assessment of primary growth of plants of these two forests in different common gardens and growth seasons, which prevents us from making direct comparisons between both species groups regarding certain growth parameters such as extension rate and duration. Since transitional forest species are adapted to higher seasonal climatic variations, we had expected that their extension patterns would be more endogenously fixed and less environmentally affected than those of rainforest species, which inhabit areas with longer periods of suitable conditions for growth, and are less exposed to extreme conditions. Although high levels of variation among species were observed concerning most aspects of growth dynamics analyzed, our predictions were only partially fulfilled. The beginning of shoot extension was highly variable for two of the transitional forest species, M. boaria and $S$. patagonicus, and for one of the rainforest species, $G$. avellana. These intra-specific variations in budbreak may also have an ontogenetic component, as indicated in studies on Nothofagus species (Stecconi et al. 2000); such a component of variability was dealt with in this study by restricting plant age and architectural stage, axis category and position of those shoots that were measured. Except for $G$. avellana, the time of extension initiation was less variable than the time of extension end. In temperate climates, the start of shoot extension is highly relevant as it determines the risk of damage by late spring frosts (Fady et al. 2003). This trait would have a complex genetic-environmental basis (Parker et al. 2017), therefore it has been proposed as a main signal of a species adaptation to local conditions (Fady et al. 2003). Low intra-specific variability of budbreak in a common-garden experiment could mean that plants are synchronized by an external signal and might exhibit high plasticity to adapt their extension periods to different conditions (Csilléry et al. 2019). Thus, co-specific individuals of those species with the lowest variations in budbreak, i.e. C. paniculata, W. trichosperma, L. apiculata, D. juncea and A. chilensis, would be able to respond coordinately to external signals such as increasing temperatures or daylength. In contrast, $M$. boaria and $S$. patagonicus had high variabilities in the time of budbreak, which could be related to genetic variability, and also had high variations in the time of $\mathrm{RER}_{\max }$. The latter results could imply that the time of RER $_{\max }$ may be conditioned by the time of budbreak in these species, and be little affected by environmental conditions. The contrary was observed for most rainforest species, in which $\mathrm{RER}_{\text {max }}$ was highly synchronized at the intra-specific scale.

In general terms, extension end was more variable than extension initiation and exhibited, contrary to our prediction, higher intra-specific variation for transitional forest than for rainforest species. The latest extension end was observed for $W$. trichosperma and C. paniculata: several plants of these species grew until early autumn, whereas most shoots of all studied species ended their extension during the summer. In a study on xylem development in conifers, it has been shown that the effect of photoperiod on cambial activity prevents shoot damage due to early frosts. Growth stops near the summer solstice (the warmest period of the year), which consequently allows lignification and cell wall production to finish early enough (Rossi et al. 2008). In the present study, although the growth season could extend beyond the warmest month of the year (January in this region; Conti 1998), the proportion of plants that did so was notably higher in the case of rainforest species with the exception of $L$. apiculata (but 
see Puntieri et al. 2018). Thus, our results provide moderate support to the idea that rainforest species are adapted to conditions in which early frosts are unlikely.

Our initial hypothesis suggested that the growth dynamics of Patagonian rainforest species is adapted to regions in which environmental limitations (frosts and droughts) are less severe in the summer. Thus, longer extension durations would be expected in rainforest than in transitional forest species. Such hypothesis could be fully confirmed by means of experimental assessment including controlled environmental conditions. This is not the case of the present study, although we observed plants in similar ontogenetic stages and under non-limiting water conditions; that means extension durations recorded for rainforest species were higher (up to 15 weeks) than those for transitional forest species. For rainforest species, our results are similar to those reported for other Patagonian rainforest species in a recent common-garden study (Sosa and Puntieri 2016). Consequently, preliminarily, these results are in accordance with our initial hypothesis. The shorter extension duration of transitional forest species could be related to shoot protection against early frosts (Fady et al. 2003), which are more common towards the eastern limit of the Argentinean Patagonian forests, and to the avoidance of the driest summer periods. Nonetheless, the transitional forest species $S$. patagonicus and $M$. boaria showed high intra-specific variability in extension initiation, end and duration, which would explain the wide distributions of these species within the E-W precipitation gradient that characterizes north-western Patagonia (Donoso 2013). These intra-specific variations could be due to genetic factors. In addition to having longer extension durations, rainforest species had higher relative extension rates than those shown by transitional forest species. It is possible that rainforest species are more adapted to interspecific competition for light, so that they may be favored by having high shootextension rates (Poorter et al. 2006).

Extension rates and temperatures. In the present study we had predicted that those species characteristic of regions with narrower ranges of within-year temperature/rainfall variations (rainforest species) would be more responsive to temperatures in terms of shoot extension rates. This prediction was confirmed for two of the studied rainforest species (W. trichosperma and G. avellana), in which extension rates were correlated to air temperatures. On the other hand, weekly variations in extension rates tended to be more responsive to temperature variations in the case of rainforest species than in transitional forest species (although $W$. trichosperma was the only RF species that was significantly different from all transitional forest species in this regard). This result complies with the idea on which this study was based and it is worth remarking that all species under survey are distributed within a similar latitudinal range (Donoso 2013). More notably so, the extension rates of $W$. trichosperma and G. avellana not only increased with temperature, but also mirrored temperature changes in magnitude. This could imply that these species would be more affected by low temperatures during the growth season than any of the other investigated species.

The only species that showed a clear peak in growth rate towards the end of the growth season was the rainforest species $C$. paniculata. The second peak constituted evidence that this species is capable of growing late in the growth season, as long as external conditions are suitable. The possibility that the extension of $C$. paniculata could be regulated by external rather than endogenous factors is supported by the fact that its apical buds are devoid of specialized leaf-derived organs (Sosa 2019). Frosts might be a weak selective pressure in rainforests; therefore, it is plausible that some species exhibit growth rate peaks near the end of the growth season. This may explain the high rates of shoot apex deaths recorded for this and other Patagonian rainforest species when growing in areas with more seasonal climate (Sosa 2019).

Gevuina avellana was the only species that had the highest AER concentrated in a few weeks during the period of the growth season when temperatures were the highest, despite having highly variable RER. We observed that the time of $\mathrm{RER}_{\max }$ was variable among individuals, nonetheless that those individuals whose $\mathrm{RER}_{\max }$ coincided with the highest temperatures were those with the highest rates. Gevuina avellana stood up from the rest of the rainforest species in its high intra-specific variations in extension initiation and time of RER max $_{\text {. }}$. This could be explained by its biogeographic origin instead of its current habitat, since G. avellana may, like other species of Gondwanan origin, belong to a linage with colder requirements (Villagrán 2018). The Gondwanan flora faced climatic changes after the breakage of the supercontinent, which caused the extinction of more than half of the species (Villagrán and Hinojosa 1997). Therefore, although G. avellana currently lives in the rainforests of Patagonia, it may have withheld functional traits that are frequent in regions under more seasonal climate, such as a highly variable $\mathrm{RER}_{\text {max }}$ or a short extension period. However, the other two rainforest species of Gondwanan origin that were considered here, i.e. W. trichosperma and C. paniculata (Aizen and Ezcurra 1998, Vasconcelos et al. 2017), differed notably from $G$. avellana in their growth patterns. When considering the Gondwanan vs Neotropical biogeographical origin of the species included in this study (based on Villagrán and Hinojosa 1997, Marx et al. 2010, Phoon 2015) apparently contradictory results arise concerning growth dynamics. Biogeographical origin, linage-history past and current selective pressures are to be considered to reach a better understanding of variability in the primary growth of trees.

Conclusions: extension patterns and climate in woody species. The distinction between rhythmic and continuous growth in trees appears, in theory, straightforward (Barthélémy and Caraglio 2007). However, seasonal cycles and 
other periodical environmental factors may blur this distinction in many world regions. The primary growth dynamics of all species under survey here could, a priori, be categorized as rhythmic; nevertheless, there are reasons to believe that environmental factors may have a significant influence on the setting of resting periods, at least for some of them. The extension features investigated in this study, such as extension initiation and end, time of RER $_{\max }$, extension duration and temperature effects on extension rate, exhibited high intra- as well as inter-specific variations under common garden conditions. Among the four rainforest species studied and despite inter- and intra-specific variability, we could establish that $W$. trichosperma and, to a lesser extent, C. paniculata, exhibit higher levels of variation in growth dynamics relative to some of the general trends that are typical to trees from temperate regions (see Kozlowski 1971).

We had proposed that, as climatic seasonality becomes sharper, the extension pattern of trees would become more 'conservative', since selection pressures would tend to reduce the possibility that sensitive newly-formed organs would be exposed to extremely cold, dry and/or dark periods of the year. Drought events and early frosts are highly likely during the summer in the region currently occupied by transitional forests, so that a strict endogenous control of growth dynamics was expected for the tree species that inhabit these forests. The less restrictive conditions under which rainforest species inhabit led us to expect a tighter growth adjustment to external conditions than to endogenous control. The differences were not as sharp as predicted, although the results found for $W$. trichosperma, $S$. patagonicus and $M$. boaria provided some support to our hypothesis. Future surveys on the growth dynamics of tree species from different forest types should not only consider current climatic conditions, but also biogeographic origin.

The results of this work show a variety of responses of the growth dynamics of tree species due to both endogenous and environmental causes. This knowledge helps to understand the adaptation of the species to the environment they occupy and allows us to predict the possible responses of the species to future climate changes. This information could be applied so as to determine sites with high conservation value and is relevant for restoration plans of the Patagonian forests. In this context, species with high endogenous variations regarding growth initiation (e.g. M. boaria and S. patagonicus) could be suitable for restoration programs in a variety of environments. The description of endogenous patterns of primary growth could be also a valuable tool for establishing protocols of nursery care for each species; for example, the length of the extension period allows determining the time-lag when irrigation or risk of frost damage are more important.

\section{ACKNOWLEDGEMENTS}

The authors thank Jardín Botánico Bariloche, INIBIOMA (UNCo-CONICET) and "Asociación Civil Sembrar" for providing nursery facilities for the essays. This work was supported by Universidad Nacional del Comahue and CONICET.

\section{REFERENCES}

Aizen M, C Ezcurra. 1998. High incidence of plant-animal mutualisms in the woody flora of the temperate forest of southern South America: biogeographical origin and present ecological significance. Ecología Austral 8: 217-236.

Barthélémy D, Y Caraglio. 2007. Plant architecture: a dynamic, multilevel and comprehensive approach to plant form, structure and ontogeny. Annals of Botany 99(3): 375-407. DOI: $10.1093 / \mathrm{aob} / \mathrm{mcl} 260$

Bates BC, ZW Kundzewicz, S Wu, JP Palutikof. 2008. Climate change and water. Technical paper of the intergovernmental panel on climate change. IPCC Secretariat, Geneva. 210 p.

Buissart F, M Vennetier, S Delagrange, F Girard, Y Caraglio, S Sabatier, AD Munson, E Nicolini. 2018. The relative weight of ontogeny, topology and climate in the architectural development of three North American conifers. $A o B$ PLANTS 10: 1-17 DOI: 10.1093/aobpla/ply045

CONAMA (Comisión Nacional del Medio Ambiente, CL). 2008. Biodiversidad de Chile, Patrimonio y Desafíos. Santiago, Chile. Ocho Libros Editores. 320 p.

Conti HA. 1998. Características climáticas de la Patagonia. In Correa MN ed. Flora Patagónica. Buenos Aires, Argentina. INTA. p. 31-47.

Csilléry K, O Ovaskainen, C Sperisen, N Buchmann, A Widmer, F Gugerli. 2019. Adaptation to local climate in a multi-trait space: evidence from silver fir (Abies alba Mill.) populations across a heterogeneous environment. Heredity 1-16. DOI: $10.1038 / \mathrm{s} 41437-019-0240-0$

Donoso C. 2013. Las especies arbóreas de los bosques templados de Chile y Argentina. Autoecología. Valdivia, Chile. Marisa Cuneo Ediciones. 678 p.

Fady B, F Ducci, N Aleta, J Becquey, R Diaz Vazquez, F Fernández López, C Jay-Allemand, F Lefèvre, A Ninot, K Panetsos, P Paris, A Pisanelli, H Rumpf. 2003. Walnut demonstrates strong genetic variability for adaptive and wood quality traits in a network of juvenile field tests across Europe. New Forests 25: 211-225.

Gerea M. 2008. Dinámica de alargamiento de los ejes en especies arbóreas de la flora valdiviana. Tesis de Licenciatura en Ciencias Biológicas, Universidad Nacional del Comahue, Bariloche, Argentina. 91 p.

Gordon D, C Damiano, TM DeJong. 2006. Preformation in vegetative buds of Prunus persica: factors influencing number of leaf primordia in overwintering buds. Tree Physiology 26: 537-544. DOI: https://doi.org/10.1093/treephys/26.4.537

Isik F, K Isik, T Yildirim, B Li. 2002. Annual shoot growth components related to growth of Pinus brutia. Tree Physiology 22: 51-58. DOI: 10.1093/treephys/22.1.51

Kozlowski TT. 1971. Growth and development in trees. Vol. I. New York, USA. Academic Press. p. 196-199.

Kitzberger T. 2012. Ecotones as complex arenas of disturbance, climate, and human impacts: the trans-Andean foreststeppe ecotone of northern Patagonia. In Myster RW ed. Ecotones between forest and grassland. New York, USA. Springer. 59-88 p. DOI: 10.1007/978-1-4614-3797-0_3 
Magnin A, R Villalba, CD Torres, M Stecconi, A Passo, CM Sosa, JG Puntieri. 2016. Effect of volcanic ash deposition on length and radial growths of a deciduous montane tree (Nothofagus pumilio). Austral Ecology 42: 103-112. DOI: https://doi.org/10.1111/aec.12405

Marx HE, N O'Leary, YW Yuan, P Lu-Irving, DC Tank, ME Múlgura, RG Olmstead. 2010. A molecular phylogeny and classification of Verbenaceae. American Journal of Botany 97(10): 1647-1663. DOI: 10.3732/ajb.1000144

Matthews T, D Mullan, RL Wilby, C Broderick, C Murphy. 2016. Past and future climate change in the context of memorable seasonal extremes. Climate Risk Management 11: 37-52. DOI: $\underline{\text { https://doi.org/10.1016/j.crm.2016.01.004 }}$

Myers N, RA Mittermeier, CG Mittermeier, GAB da Fonseca, J Kent. 2000. Biodiversity hotspots for conservation priorities. Nature 403: 853-858. https://www.nature.com/articles/35002501

Parker TC, J Tang, MB Clark, MM Moody, N Fetcher. 2017. Ecotypic differences in the phenology of the tundra species Eriophorum vaginatum reflect sites of origin. Ecology and Evolution 7: 9775-9786. DOI: https://doi.org/10.1002/ ece3.3445

Phoon SN. 2015. Systematics and biogeography of Elaeocarpus (Elaeocarpaceae). PhD thesis. Cairns, Australia. James Cook University. 303 p.

Poorter L, L Bongers, F Bongers. 2006. Architecture of 54 moist-forest tree species traits, trade-offs, and functional groups. Ecology 87(5): 1289-1301. DOI: 10.1890/0012-9658(2006)87[1289:AOMTST]2.0.CO;2

Premoli A, E Raffaele, P Mathiasen. 2007. Morphological and phenological differences in Nothofagus pumilio from contrasting elevations: Evidence from a common garden. Austral Ecology 32: 515-523. DOI: 10.1111/j.14429993.2007.01720.x

Puntieri J, C Torres, A Magnin, M Stecconi, J Grosfeld. 2018. Structural differentiation among annual shoots as related to growth dynamics in Luma apiculata. Flora 249: 86-96. DOI: $10.1016 /$ j.flora.2018.10.005

R Development Core Team. 2014. R: A language and environment for statistical computing. R Foundation for Statistical Computing, Vienna.

Rossi S, A Deslauriers, J Griçar, J Seo, CBK Rathgeber, T Anfodillo, H Morin, T Levanic, P Oven, R Jalkanen. 2008. Critical temperatures for xylogenesis in conifers of cold climates. Global Ecology and Biogeography 17: 696-707. DOI: https://doi.org/10.1111/j.1466-8238.2008.00417.x

Salgado M. 2018. Dinámica de crecimiento primario de brotes anuales de las especies nativas leñosas Aristotelia chilensis, Maytenus boaria, Schinus patagonicus y Diostea juncea en condiciones de vivero. Tesis de Licenciatura en Ciencias Biológicas, Universidad Nacional del Comahue, Bariloche, Argentina. 79 p.

Sosa C, JG Puntieri. 2016. Crecimiento anual de cuatro especies arbóreas con yemas desnudas nativas de los bosques templados húmedos de Patagonia. Boletín de la Sociedad Argentina de Botánica 51(4): 643-655. DOI: 10.31055/1851.2372. v51.n4.16341

Sosa C. 2019. Aspectos básicos del crecimiento y la morfo-arquitectura de especies arbóreas de la Selva Valdiviana. $\mathrm{PhD}$ thesis. Bariloche, Argentina. Universidad Nacional del Comahue. 149 p.

Sow MD, I Allona, C Ambroise, D Conde, R Fichot, S Gribkova, V Jorge, G Le-Prevost, L Pâques, C Plomion, J Salse, L Sanchez-Rodriguez, V Segura, J Tost, S Maury. 2018. Epigenetics in forest trees: state of the art and potential implications for breeding and management in a context of climate change. In Gallusci P, E Bucher, M Mirouze eds. Plant epigenetics coming of age for breeding applications. New York, USA. Academic Press. p. 387-453.

Stecconi M, J Puntieri, D Barthélémy. 2000. Annual shootgrowth of Nothofagus antarctica (G. Forster) Oersted (Nothofagaceae) from northern Patagonia. Trees: Structure and Function 14: 289-296.

Stecconi M, L Quevedo, A Magnin, C Torres, K Lediuk, M Svriz, JE Grosfeld, JG Puntieri. 2017. Desarrollo de especies leñosas nativas y exóticas en cipresales patagónicos. Boletín de la Sociedad Argentina de Botánica 52(2): 507-522. DOI: https://doi.org/10.31055/1851.2372.v52.n3.18030

Vasconcelos TNC, CEB Proença, B Ahmad, DS Aguilar, R Aguilar, BS Amorim, K Campbell, IR Costa, PS De-Carvalho, JEQ Faria, A Giaretta, PW Kooij, DF Lima, FF Mazine, B Peguero, G Prenner, MF Santos, J Soewarto, A Wingler, EJ Lucas. 2017. Myrteae phylogeny, calibration, biogeography and diversification patterns: Increased understanding in the most species rich tribe of Myrtaceae. Molecular Phylogenetics and Evolution 109: 113-137. DOI: 10.1016/j.ympev.2017.01.002

Villagrán C, F Hinojosa. 1997. Historia de los bosques del sur de Sudamérica, II: Análisis fitogeográfico. Revista Chilena de Historia Natural 70: 241-267.

Villagrán C. 2018. Biogeografía de los bosques subtropical-templados del sur de Sudamérica. Hipótesis históricas. Magallania 46(1): 27-48. DOI: http://dx.doi.org/10.4067/S0718$\underline{22442018000100027}$ 